\title{
OPTIMIZATION OF CONSTRUCTIVE AND TECHNOLOGICAL SOLUTIONS OF HIGH-RISE ENGINEERING STRUCTURES EMERGENCY MEASURES
}

\section{Menejljuk O. I.}

\section{INTRODUCTION}

There is a large number of high-rise engineering structures in Ukraine and abroad. Most of them are operated by ten years or more. Many high-rise engineering facilities require repair work, and some - emergently. Such projects require a significant investment. As a rule, there are many options for the upgrade. They may have different costs, deadlines. The specificity of some objects requires a specific schedule (only on the night shift, the use of a limited number of people or calendar time). The regulations and information sources have no guidance on the selection of effective organizational and technological decisions at reconstruction of such buildings.

The use of traditional building processes modeling methods makes it impossible to evaluate the effectiveness of variants of organizational and technological solutions. Modeling of these options and experimental analysis of statistical models will determine the best solution for the selected performance criteria.

\section{Analysis of information sources}

To solve the problem of optimizing the project emergency measures radio tower them. Shukhov was conducted numerical experiment on modeling options of organizational solutions to these works. When carrying out a numerical study used the theory of optimal experimental design, experimental and statistical modeling, advanced software for the construction of the calendar-network models construction industry ${ }^{1,2,3}$. The numerical study of the developed algorithm allows to reasonably choose the

\footnotetext{
${ }^{1}$ Вознесенский В.А. Статистические методы планирования эксперимента в техникоэкономических исследованиях / В.А. Вознесенский // М.: Финансы и статистика, 1981. 263 c. 7.

2 Адлер Ю.П. Планирование эксперимента при поиске оптимальных условий / Ю.П. Адлер, Е.В. Маркова, Ю.В. Грановский // М. : Наука. - 1-е изд., 1971. - 283 с. 2-е изд., 1976. - $279 \mathrm{c.}$

${ }^{3}$ Налимов В.В. Теория эксперимента. / В.В. Налимов // М. : Наука, 1971. - 208 с.
} 
optimal design and technological solutions for the complex restoration work in difficult conditions, with limited institutional financing ${ }^{4,5}$.

\section{The optimization algorithm design and technological solutions emergency measures}

Optimization tasks solution consists of the following steps:

Analysis of design estimates for the project emergency measures, which are the first of the planned phases of the restoration of the tower it. Shukhov; choice of design and technological design solution alternatives, the choice of optimization criteria and plan of numerical experiment;

bigger the calculation and construction of the calendar-network models of complex emergency measures in MS Project program in accordance with the selected plan of numerical experiment;

mathematical processing of the simulation results is constructivetechnological decisions of emergency measures;

selection of optimal design and technological parameters in accordance with the existing limitations in technology, organization and project financing emergency measures.

The study used estimates, reflecting actual costs of construction and installation works. Building renovation schedules can correctly display the sequence and adopted technological solutions during work at height. The technique allows a quantitative assessment of alternatives to structural and technological solutions with varying versions of the complex organization of emergency response work, financing conditions and existing restrictions.

Fig. 1 shows a block diagram of a research methodology for optimizing project emergency measures on the tower Shukhov.

After creating models (diagrams) of building production on the basis of approved plan of numerical experiment should build ES model complex emergency measures. The construction of ES model is to find the coefficients of a mathematical model that adequately describes the emergency project work within the prescribed limits of the factor space. ES model will build according to the most important indicators of the influencing factors, make their analysis, to investigate the optimum area according to selected criteria.

\footnotetext{
${ }^{4}$ Краковский Г.И. Планирование экспериментов / Г.И. Краковский, Г. Ф. Филаретов. // Минск: БТУ, 1982. - 757 с.

${ }^{5}$ Вознесенский В.А. Численные методы решения строительно-технологических задач на ЭВМ / В.А. Вознесенский, Т.В. Ляшенко, Б.Л. Огарков // К. : Вища школа, 1989.-328. с.
} 


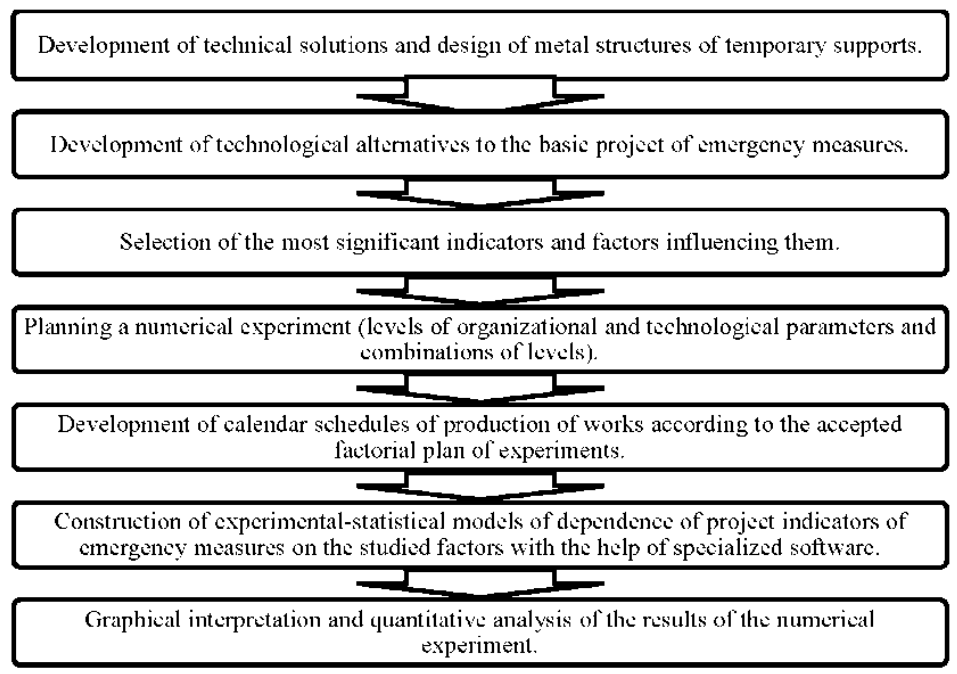

\section{Fig. 1. Block diagram of the research methodology for optimizing project emergency measures on the tower it. Shukhov}

Below is an algorithm analyzing the survey results.

1. Preliminary analysis of the most common patterns of the study by the analysis of the matrix (table) of experiment results.

2. Building a basic multidimensional graphs of performance of all the factors, their analysis and the search for areas of factor space, containing the optimum point.

3. The ranking factors in the degree of influence on the average values in the area factors.

4. Comparison of several points optimum for the selected criteria: organizational, technological, financial and others.

5. Construction of multi-dimensional charts and with the introduction of restrictions on the values of parameters and factors.

6. Construction of the final organizational and technological models of emergency measures taking into account the optimal solution and the required detail.

\section{The rationale for the plan to construct a numerical experiment ES model}

Emergency measures consist in the construction of temporary structures within the pillars of the tower it. Shukhov followed by «hanging» of the 
elements of the tower, which will reduce the load on the supporting structures of the emergency facilities. Subsequently temporary structures may be used as supports for the building production during reconstruction of the tower. After the reconstruction and implementation of the necessary measures for the preservation of cultural heritage object it is planned to dismantle the temporary supports.

Draft emergency measures includes the following work package:

dismantling works;

apparatus pile foundation and monolithic grillage for temporary supporting structures:

fabrication and installation of supports of metal structures;

«Hanging out» elements of the tower it. Shukhov;

priming and painting of steel structures.

The main work during the complex emergency response activities are the manufacture and installation of temporary support structures. The design documentation shows the device columns of temporary structures of hollow tube 1020 and a diameter of $720 \mathrm{~mm}$., Followed by their partial filling with concrete. The joints of tubular columns, as well as compounds in knots abutting columns, connections, spacers and consoles temporary supporting structures made welded. However, the device a large number of welded connections at a considerable height $(100 \mathrm{~m}$.) Is problematic. In this regard, it is accepted as an alternative technology to perform device columns flanged joints, bolted joints. To save money and human resources proposed to reduce the height of the steel columns filled with concrete.

The following indicators are taken as the most significant:

Duration mounting temporary supporting structures (Y1) - a period of works, comprising the assembly of metal columns, connections, struts, ladders and platforms, as well as the operation for filling the concrete columns.

The full cost of the project with charges (Y2) - the sum of direct costs and fixed costs on emergency measures. Direct costs are taken in accordance with the budget documentation, taking into account the estimated coefficients and the necessary charges. Fixed costs accepted by an expert estimation of 500 thousand. Rub. / Month.

The intensity of the funding for the project (Y3) - ratio of the total cost of the complex emergency measures to the full duration, expressed in months.

The factors most significantly influencing the specified indicators were adopted: 
Embodiments constructive and technological solutions devices temporary supporting structures (CTE):

1. device via welds temporary supporting structures in the form of hollow columns with subsequent filling with concrete to the level of $24.65 \mathrm{~m}$ - KTR1.;

2. the use of flanges at the device temporary supporting structures in the form of hollow columns filled with concrete to the level of $1.50 \mathrm{~m}$, provided an increase of the wall thickness of tubular members -. KTR2.

The degree of integration of elements mounted columns (X1) conventionally involves continuous changes in the degree of integration of elements within a weight member mounted from 1 to $10 \mathrm{~m}$ This corresponds to the minimum and maximum possible weight of elements in view of payload mechanisms work conditions of production and safety..

The number of workers employed in the installation of metal structures (X2) - adopted in the range of 5 to 15 people. The factor takes into account the possibility of setting one, two or three pulley service. The total number of work is divided into units in accordance with the presence pulley.

It should be noted that the factor «variants constructive and technological solutions temporary supporting structures» refers to a type of «value.» This means that the levels of this factor are discrete, they can not be described using a numerical scale. The levels of the factor identified as KRT1 and KRT2. Therefore plan comprises two series of experiments with single scale levels of indicators of units and X1 factors (degree of integration of elements mounted columns) and X2 (the number of workers employed in assembly of steel structures). These two series form two factorial subspace - for KTR1 and KTR2. The plan of this type will properly compare the results of two series of experimental studies in conventionally single factor space.

The experimental design using the factors given above, is shown in table 1.

\section{Prerequisites for the calculation}

To determine the correct values of labor and cost estimate documentation was used in the production of works. According to the results of its analysis with a special MS Excel Tool - «pivot tables» - was composed table 2 Containing a bigger range of works, their estimated complexity and cost. In drawing up the estimates are generally used basic prices, for example, 2001. Inflation, location of the facility and other charges are taken into account only when determining the final amount.

Therefore, in the above amounts (Table. 2) Conventionally adopted the same for all work transfer coefficient taking into account the above 
calculation. The coefficient was calculated by dividing the total estimated cost calculated on the amount of direct costs.

Table 1

\section{Experimental Design}

\begin{tabular}{|c|c|c|c|c|}
\hline \multirow{2}{*}{ 离 } & \multicolumn{2}{|c|}{$\begin{array}{l}\text { The degree of pre-assembly mounted } \\
\text { element } M \text { / K columns }\left(X_{1}\right) \% \text {. }\end{array}$} & \multicolumn{2}{|c|}{$\begin{array}{l}\text { The number of workers employed in } \\
\text { the installation of } \mathrm{M} / \mathrm{K}\left(\mathrm{X}_{2}\right) \text {, pers. }\end{array}$} \\
\hline & normalized values & actual values & normalized values & actual values \\
\hline \multicolumn{5}{|c|}{ Structural and technological solutions №1- KTR1 } \\
\hline 1.1 & -1 & $0 \%$ & -1 & 5 \\
\hline 1.2 & 0 & $50 \%$ & -1 & 5 \\
\hline 1.3 & +1 & $100 \%$ & -1 & 5 \\
\hline 1.4 & -1 & $0 \%$ & 0 & 10 \\
\hline 1.5 & 0 & $50 \%$ & 0 & 10 \\
\hline 1.6 & +1 & $100 \%$ & 0 & 10 \\
\hline 1.7 & -1 & $0 \%$ & +1 & 15 \\
\hline 1.8 & 0 & $50 \%$ & +1 & 15 \\
\hline 1.9 & +1 & $100 \%$ & +1 & 15 \\
\hline \multicolumn{5}{|c|}{ Structurally-technological solution №2 - KTR2 } \\
\hline 2.1 & -1 & $0 \%$ & -1 & 5 \\
\hline 2.2 & 0 & $50 \%$ & -1 & 5 \\
\hline 2.3 & +1 & $100 \%$ & -1 & 5 \\
\hline 2.4 & -1 & $0 \%$ & 0 & 10 \\
\hline 2.5 & 0 & $50 \%$ & 0 & 10 \\
\hline 2.6 & +1 & $100 \%$ & 0 & 10 \\
\hline 2.7 & -1 & $0 \%$ & +1 & 15 \\
\hline 2.8 & 0 & $50 \%$ & +1 & 15 \\
\hline 2.9 & +1 & $100 \%$ & +1 & 15 \\
\hline
\end{tabular}

In the analysis of table 2 it is clear that the estimated cost of works on manufacturing and installation of metal columns vary depending on the type of CTE. The change in the cost due to the fact that the manufacture and installation of steel structures bolted to consider the cost of flanges, bolts, nuts and washers.

For correct charting construction Erection of columns, connections, spacers, stairs and platforms were divided into separate processes, appropriate technology zahvatki. Separately allocated processes preassembly and assembly of steel structures of columns, since these processes are the direct object of the optimization of the study. When constructing schedules an object was divided into four technology tiers:

1. elevations in 0.00: $24.65 \mathrm{~m}$;

2. in elevation 24.65: $46.40 \mathrm{~m}$;

3. in elevation 46.40: $73.10 \mathrm{~m}$;

4. in elevation 73.10: $98.10 \mathrm{~m}$. 
Table 2

Analysis of labor input and cost estimates

\begin{tabular}{|c|c|c|c|c|}
\hline \multirow[t]{2}{*}{ titles of works } & \multicolumn{2}{|c|}{$\begin{array}{l}\text { Labor costs, } \\
\text { man-hours. }\end{array}$} & \multicolumn{2}{|c|}{ Costs by a factor rubles. } \\
\hline & KTR2 & KTR1 & KTR2 & KTR1 \\
\hline Disassembly & 4987.85 & 4987.85 & 29193876.81 & 29193876.81 \\
\hline $\begin{array}{l}\text { Helicopter dismantling } \\
\text { 7th Section }\end{array}$ & 378 & 378 & 26325451.04 & 26325451.04 \\
\hline $\begin{array}{c}\text { Removal of metal staircase and } \\
\text { platforms }\end{array}$ & 1260,00 & 1260,00 & 767299.56 & 767299.56 \\
\hline Dismantling of freight elevator & 1602,00 & 1602,00 & 160483.37 & 160483.37 \\
\hline dismantling of foundations & 1664.96 & 1664.96 & 1809138.96 & 1809138.96 \\
\hline Debris removal & 82.89 & 82.89 & 131503.87 & 131503.87 \\
\hline $\begin{array}{c}\begin{array}{c}\text { Apparatus pile foundation, } \\
\text { concrete }\end{array} \\
\end{array}$ & 1676.99 & 3934.44 & 3857162.55 & 7745534.01 \\
\hline CFA piling apparatus & 1286.33 & 1286.33 & 2861624.22 & 2861624.22 \\
\hline Apparatus monolithic grillage & 253.72 & 253.72 & 759675.24 & 759675.24 \\
\hline $\begin{array}{l}\text { Concreting of columns } \\
\text { supporting structures }\end{array}$ & 136.93 & 2394.39 & 235863.09 & 4124234.55 \\
\hline Metal Fabrication & 35543,00 & 33739,00 & 37316007.30 & 34244250.46 \\
\hline Production M / K Gain & 32243,00 & 30439,00 & 34191773.19 & 31120016.36 \\
\hline $\begin{array}{l}\text { Production M / K ladders and } \\
\text { platforms }\end{array}$ & 3300,00 & 3300,00 & 3124234.11 & 3124234.11 \\
\hline installation of metal structures & 24988.28 & 24988.28 & 18573914.60 & 17502538.62 \\
\hline $\begin{array}{l}\text { Fitting mounting devices } \\
\text { and guards }\end{array}$ & 1281,00 & 1281,00 & 337750.02 & 337750.02 \\
\hline Installation of M / K columns & 4537.53 & 4537.53 & 5970942.92 & 4899566.94 \\
\hline $\begin{array}{c}\text { Installation of } \mathrm{M} / \mathrm{K} \text { ties and } \\
\text { braces }\end{array}$ & 5936.53 & 5936.53 & 4625307.16 & 4625307.16 \\
\hline $\begin{array}{l}\text { Installation of } \mathrm{M} / \mathrm{R} \text { ladders } \\
\text { and platforms }\end{array}$ & 4046.22 & 4046.22 & 2955998.34 & 2955998.34 \\
\hline «Hanging out» elements of tower & 9187,00 & 9187,00 & 4683916.17 & 4683916.17 \\
\hline Corrosion protection of metal & 9149,00 & 9149,00 & 2911680.68 & 2911680.68 \\
\hline $\begin{array}{c}\text { Installation and removal of } \\
\text { construction equipment }\end{array}$ & 8350,00 & 8350,00 & 1582260.07 & 1582260.07 \\
\hline $\begin{array}{l}\text { Cleaning brushes metal } \\
\text { structures }\end{array}$ & 605 & 605 & 130900.29 & 130900.29 \\
\hline $\begin{array}{l}\text { Prime-coating of metal } \\
\text { constructions }\end{array}$ & 32 & 32 & 32365.87 & 32365.87 \\
\hline Coatings & 162 & 162 & 1166154.45 & 1166154.45 \\
\hline The overall result & 76345.12 & 76798.58 & 91852641.94 & 91597880.59 \\
\hline
\end{tabular}

Linking works in all charts was performed taking into account the mainstreaming of work: while one team of installers performs high-altitude installation spacers and consoles, the second performs pre-assembly of columns for the next tier, installation of ladders and platforms on the lower tier. Safety production work in this case is provided by the mutual displacement of teams in the horizontal plane. Analysis performed graphs 
showed that the pre-assembly process columns, installation of stairs and platforms are not on the critical path. To select options for execution of works was drawn up a list of process steps for the construction of columns of temporary structures for various structural and technological solutions. It is indicated intable 3 . The table contains the distribution of resources between cost manufacturing operations at constructive and technological solutions №1 and №2 and different levels of factor $\mathrm{X}_{1}$. This allocation is made on the results of expert evaluation. It should be noted that the operations for assembly and installation of consolidated elements of columns (rows 1 and 5Table. 3) Have different resource allocation costs for two types of constructive and technological solutions elements of metal constructions. With the help of factors taken into account the difference in the amount of labor and cost.

At table 3 allocated different levels of factor $X_{1}$, as shown in the respective columns (columns 2, 3 and 4). Note that the resource costs for transporting and installing the different elements of metal constructions columns (rows 2, 3, 4 and 6 Table. 3). The difference is due to changes in the production process. Analysis coefficients shows they are inversely proportional to the degree of integration of mounted element.

Line 7 table 3 represents the sum of the coefficients of each mounting operation. Thus obtained final correction coefficient. It is used to adjust the values of labor and cash costs, which were subsequently made to the work of production schedules. For convenience, the correction factors are shown separately for works on pre-assembly and assembly of the elements in the design position (lines 8, 9 table 3 ).

\section{Results of experimental statistical modeling}

In this section, The analysis of the results of research on the optimization of the project emergency measures on the tower Shukhov. The object of this study is the optimization process of erecting temporary supporting structures. Their purpose - to support emergency facility before and during the work on the upgrade. Optimization of design and technological solutions aimed at accelerating the process of reduction in price and construction of temporary structures and their dismantling after the restoration of the main structures of the tower.

In order to optimize the project emergency work was carried out experimentally-statistical simulation of the construction of temporary supports. The following parameters were investigated in the modeling process:

duration mounting temporary supporting structures $\left(\mathrm{Y}_{1}\right)$;

total project costs with charges $\left(\mathrm{Y}_{2}\right)$;

the intensity of the funding for the project $\left(\mathrm{Y}_{3}\right)$. 
On the figures shown above are the most affected by the following factors:

Table 3

\section{Coefficients resource allocation costs of technological operations} and correction coefficients depending on the degree of pre-assembly

\begin{tabular}{|c|c|c|c|}
\hline $\begin{array}{c}\text { Technological } \\
\text { operation designation }\end{array}$ & $\begin{array}{c}\text { The coefficient of } \\
\text { installing } M / K \\
\text { without } \\
\text { preassembly } \\
\text { (conventional } \\
\text { element weight } \\
1 \text { ton) }\end{array}$ & $\begin{array}{l}\text { The coefficient of } \\
\text { installing } \mathrm{M} / \mathrm{K} \\
\text { with a degree of } \\
\text { pre-assembly } 50 \% \\
\text { (conditional } \\
\text { weight element } \\
5 \mathrm{~m} \text { ) }\end{array}$ & $\begin{array}{c}\text { The coefficient of } \\
\text { installing } M / K \\
\text { with a degree of } \\
\text { pre-assembly } \\
100 \% \\
\text { (conventional } \\
\text { element weight } \\
10 \text { tons) }\end{array}$ \\
\hline $\begin{array}{c}\text { Pre-assembly mounted } \\
\text { element M / K (at } \\
\text { KTR1 / KTR2) }\end{array}$ & $0 / 0$ & $0.52 / 0.346$ & $0.585 / 0.39$ \\
\hline $\begin{array}{l}\text { Installation of the } \\
\text { lifting devices }\end{array}$ & 0,025 & 0,005 & 0.0025 \\
\hline $\begin{array}{c}\text { Hoisting element } \mathrm{M} / \\
\mathrm{K} \text { to the installation } \\
\text { site }\end{array}$ & 0.1 & 0.02 & 0.01 \\
\hline $\begin{array}{l}\text { Installation and } \\
\text { alignment of the } \\
\text { mounted element }\end{array}$ & 0.2 & 0.04 & 0.02 \\
\hline $\begin{array}{c}\text { Installation in design } \\
\text { position (at KTR1 / } \\
\text { KTR2) }\end{array}$ & $0.65 / 0.433$ & $0.13 / 0.086$ & $0.065 / 0.043$ \\
\hline Removing slinging & 0,025 & 0,005 & 0.0025 \\
\hline $\begin{array}{c}\text { Total correction } \\
\text { factor }\end{array}$ & $1 / 0,783$ & $0.72 / 0.502$ & $0.685 / 0.468$ \\
\hline $\begin{array}{c}\text { including } \\
\text { in the pre-assembly }\end{array}$ & $0 / 0$ & $0.52 / 0.346$ & $0.585 / 0.39$ \\
\hline $\begin{array}{c}\text { including } \\
\text { transportation to the } \\
\text { installation site and } \\
\text { the installation in } \\
\text { design position }\end{array}$ & $1 / 0,783$ & $0.2 / 0.156$ & $0.1 / 0.078$ \\
\hline
\end{tabular}

variants of constructive and technological solutions devices temporary supporting structures (KTR1 or KTR2);

the degree of integration of elements mounted columns $\left(\mathrm{X}_{1}\right)$;

the number of workers employed in the installation of metal structures $\left(\mathrm{X}_{2}\right)$.

the experimental results shown in the matrix table 4. It shows the values of parameters at different points of the space factor, and varying levels of factors, for which the corresponding values of the indicators were obtained. 
Table 4

Matrix of research results

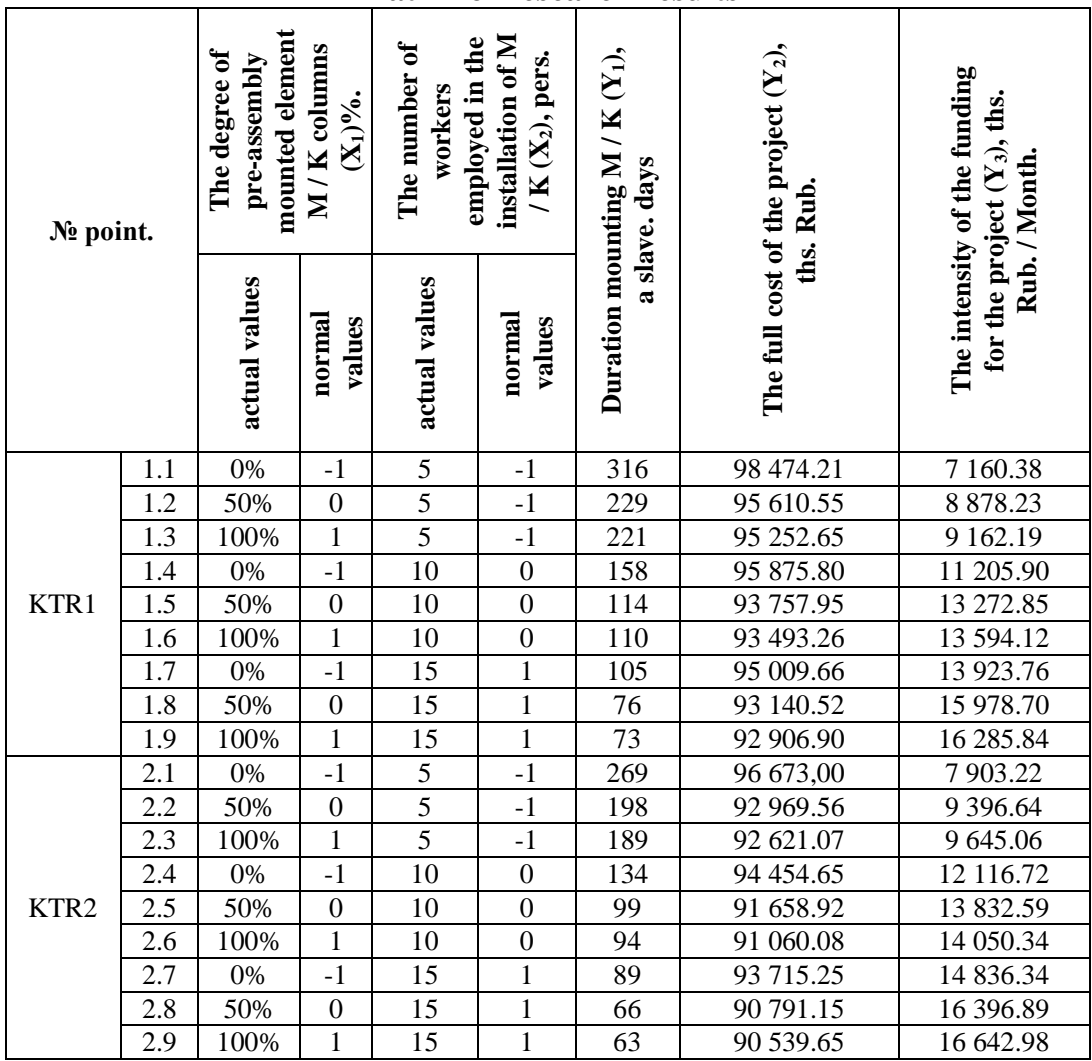

Let us analyze table 4 . Note that the figures «prolonged erection of temporary supporting structures» and «full cost of implementing the project with charges» have somewhat lower values at KTR2. This observation is true in all areas of the factor space. For the values of the indicator «intensity of project financing» change factor level «versions structural and technological solutions» does not have a significant impact.

Formula 1 and 2 Electric models are index «duration temporary supporting structures mounted» in analytical form (with and KTR2 KTR1). On Figure 2 these models are presented in graphical form.

$Y_{1}^{\mathrm{KTP} 1}=\operatorname{EXP}\left(4,744-0,179 x_{1}+0,14 x_{1}^{2}+\bullet-0,549 x_{2}+0,144 x_{2}^{2}\right) ;(1)$ 


$$
\begin{gathered}
Y_{1}^{\mathrm{KTP} 2}=\operatorname{EXP}\left(4,593-0,167 x_{1}+0,138 x_{1}^{2}+\right. \\
\left.+0,012 x_{1} x_{2}-0,541 x_{2}+0,152 x_{2}^{2}\right)
\end{gathered}
$$

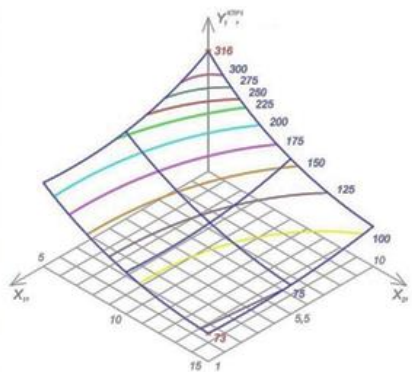

Structurally-technological solution № 1 (KTR1)

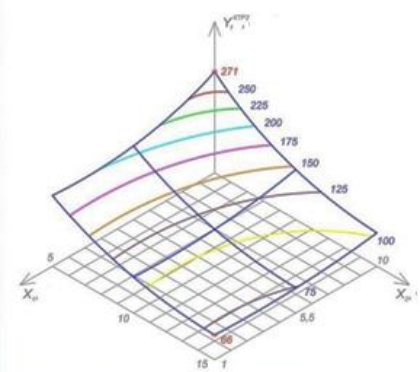

Structurally-technological solution № 2 (KTR2)

Fig. 2. Laws of the indicator «duration temporary supporting structures mounted» when different constructive variants, technological solutions temporaries columns

Formula 3 and 4 ES models are the indicator «total project costs with charges» in the closed form (at KTR1 and KTR2). On Figure 3 these models are presented in graphical form.

$$
\begin{gathered}
Y_{2}^{\mathrm{KTP} 1}=\operatorname{EXP}\left(11,449-0,012 x_{1}+0,009 x_{1}^{2}+\bullet-0,013 x_{2}\right. \\
\left.\quad+0,006 x_{2}^{2}\right) ; \\
Y_{2}^{\mathrm{KTP} 2}=\operatorname{EXP}\left(11,424-0,019 x_{1}+0,015 x_{1}^{2}+0,002 x_{1} x_{2}\right. \\
\left.-0,013 x_{2}+0,005 x_{2}^{2}\right) ;
\end{gathered}
$$

Formula 5 and 6 ES models are the indicator «intensity of financing for the project» in an analytical form (if KTR1 and KTR2). On Figure 4 these models are presented in graphical form.

$$
\begin{gathered}
Y_{3}^{\mathrm{KTP} 1}=E X P\left(9,494+0,1 x_{1}-0,075 x_{1}^{2}-0,022 x_{1} x_{2}+0,305 x_{2}\right. \\
\left.-0,11 x_{2}^{2}\right) ; \\
Y_{3}^{\mathrm{KTP} 2}=\operatorname{EXP}\left(\begin{array}{c}
9,535+0,077 x_{1}-0,058 x_{1}^{2}-0,021 x_{1} x_{2} \\
\left.+0,289 x_{2}-0,108 x_{2}^{2}\right) ;
\end{array}\right.
\end{gathered}
$$


Analysis Fig. 2 shows that the variation index $Y_{1}$ «duration mounting temporary supporting structures» is slightly different depending on the adopted embodiment CTE. Both in one and in another case the minimum value of the factor levels $\left(\mathrm{X}_{1}=1 \mathrm{X}_{2}=5\right.$ pers. $)$ Correspond to the maximum value of the index $Y_{1 \text { max }}^{\mathrm{KTP} 1}=316,0$ days. $Y_{1 \text { max }}^{\mathrm{KTP} 2}=271,2$ day. At levels $\left(\mathrm{X}_{1}=1 ; \mathrm{X}_{2}=15\right.$ persons $)$ modeling showed a minimum value of the index $Y_{1 \text { min }}^{\mathrm{KTP} 1}=73,7$ day. The minimum index in the case in point is KTR2 $Y_{1 \min }^{\mathrm{KTP2}}=65,8$ day $\left(\mathrm{X}_{1}=10 \mathrm{~m}\right.$.; $\mathrm{X}_{2}=15$ pers. $)$.

According to the analysis Fig. 3 it can be concluded that the behavior of the index $\mathrm{Y}_{2}$ «total project costs with charges» slightly varies depending on the type of CTE columns. In both types the maximum index point is at coordinates $\left(\mathrm{X}_{1}=1 \mathrm{X}_{2}=\mathrm{T}\right.$.; 5 pers.) (Th. Rub .; thousand. Rub.). Minimum points coincide coordinates $\left(\mathrm{X}_{1}=10 \mathrm{~m}\right.$.; $\mathrm{X}_{2}=15$ pers.): Th. Rub .; thousand roubles. There is a difference in the index values of different factorial subspace (with KTR1 and KTR2). $Y_{2 \max }^{\mathrm{KTP} 1}=97635,84 Y_{2 \max }^{\mathrm{KTP2}}=$ $96567,73 Y_{2 \mathrm{~min}}^{\mathrm{KTP} 1}=92874,09 Y_{2 \mathrm{~min}}^{\mathrm{KTP} 2}=90581,02$

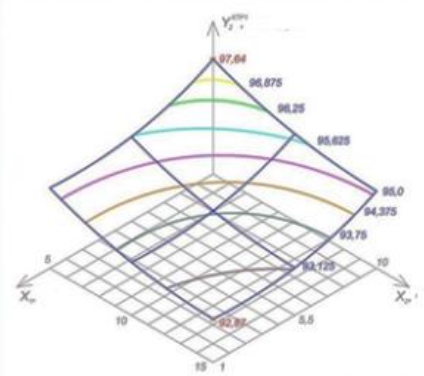

Structurally-technological solution № 1 (KTR1)

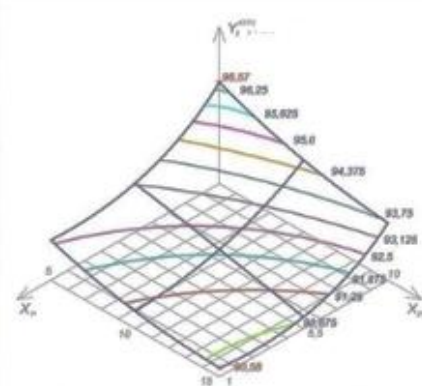

Structurally-technological solution № 2 (KTR2)

Fig. 3. Laws of change of the indicator «total project costs with charges» when using different options for structural and technological solution of temporary structures columns

It is due to both a decrease in direct costs, and a decrease in fixed costs for the whole project in the case of KTR2. In general, the use KTR2 saves 1.1 to 2.3 Mill. Rubles with various combinations of other factors.

Let us analyze Figure 4. On it show the indicator «the intensity of the funding for the project» for different types of steel structures CTE. The nature of the indicator is slightly different in different subspaces factor.

The coordinates of the minimum and maximum indicator and coincide when KTR1 KTR2. So, ths. Rub. / Month. ( $\mathrm{X}_{1}=10 \mathrm{~m}$.; $\mathrm{X}_{2}=15$ persons). 
thousand. rub. / month. ( $\mathrm{X}_{1}=1 \mathrm{X}_{2}=\mathrm{T}$;; 5 persons). thousand. rub. / month. $\left(\mathrm{X}_{1}=10 \mathrm{~m}\right.$.; $\mathrm{X}_{2}=15$ persons $)$. thousand. rub. / month. $\left(\mathrm{X}_{1}=1 \mathrm{X}_{2}=\mathrm{T}\right.$.; 5 pers.).

$$
\begin{aligned}
Y_{3 \mathrm{max}}^{\mathrm{KTP} 1} & =16187,58 Y_{3 \mathrm{~min}}^{\mathrm{KTP} 1}=7201,17 Y_{3 \mathrm{max}}^{\mathrm{KTP} 2}= \\
& =16547,66 Y_{3 \mathrm{~min}}^{\mathrm{KTP} 2}=7958,53
\end{aligned}
$$

On Figure 5 ranking diagram showing degrees of influence factors $\mathrm{X} 1$ and X2 on the studied parameters. The diagrams are constructed for different factorial subspace (KTR1 and KTR2). Note that in figures «duration temporary supporting structures mounted» $\left(\mathrm{Y}_{1}\right)$ and the «intensity of project funding» $\left(\mathrm{Y}_{3}\right)$ the degree of influence factors $\mathrm{X}_{1}$ and $\mathrm{X}_{2}$ varies slightly when moving CTE embodiment. For the record, «the full cost of the project with charges» $\left(\mathrm{Y}_{2}\right)$ the degree of influence of different factors: the KTR1 has great influence factor $\mathrm{X}_{2}$, at KTR2 - $\mathrm{H} 1$.

Figures 6-8 allows us to compare the behavior of the parameters depending on the level of factor $\mathrm{X}_{1}$ (the degree of integration of elements mounted columns). In this case $X_{2}$ factor (number of workers employed in assembly of steel structures) is fixed at one of three levels: 1, 0, 1 (5, 10 and 15 work respectively).

In the figure, graphics performance changes in different constructive variants, technological solutions are combined in a single chart.

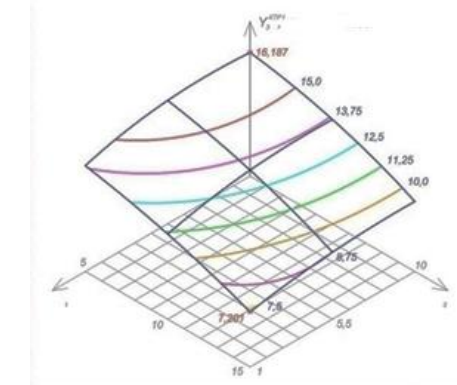

Structurally-technological solution № 1 (KTR1)

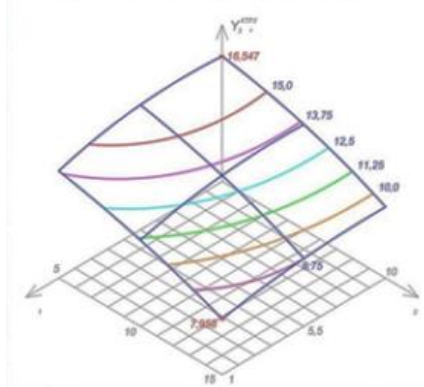

Structurally-technological solution № 2 (KTR2)

Fig. 4. Laws of change of the indicator «intensity of financing for the project» using different variants of constructive and technological solutions temporaries columns 


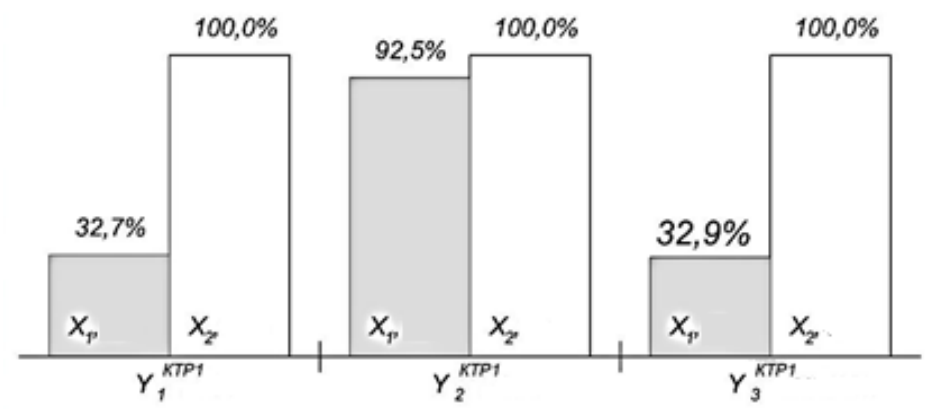

Structurally-technological solution № 1 (KTR1)

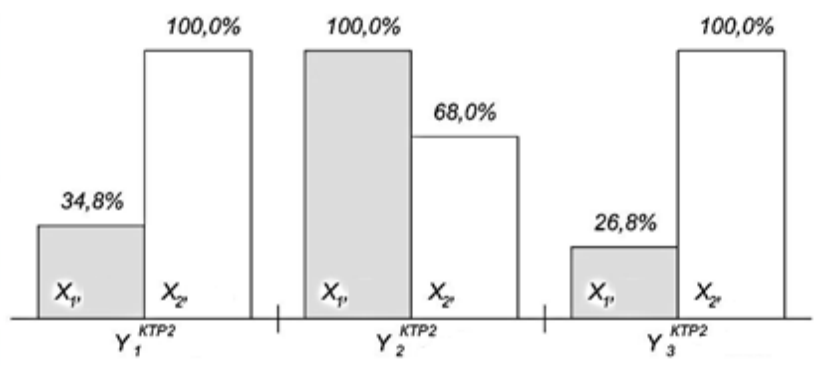

Structurally-technological solution №2 (KTR2)

Fig. 5. Ranking the degree of influence of factors $X_{1}$ and $X_{2}$ on the studied parameters using the different options of temporary structures CTE columns

In the analysis of Fig. 6 it is clear that the behavior of the index $\mathrm{Y}_{1}$ (time duration bearing designs of installation) under the influence of factor $X_{1}$ is different. It depends on the level of factor $\mathrm{X}_{2}$. The difference between the extreme values of the response function at $X_{2}=5$ people. It is as follows: 95.1 days for KTR1; 81.6 days for KTR2.

When $\mathrm{X}_{2}=-1$, this difference amounts to 31.7 and 23.9 days, respectively. $X_{1}$ factor affects the rate considerably less than a factor $X_{2}$, and can change it to 1.36-1.43 times (for different subspaces factor). 


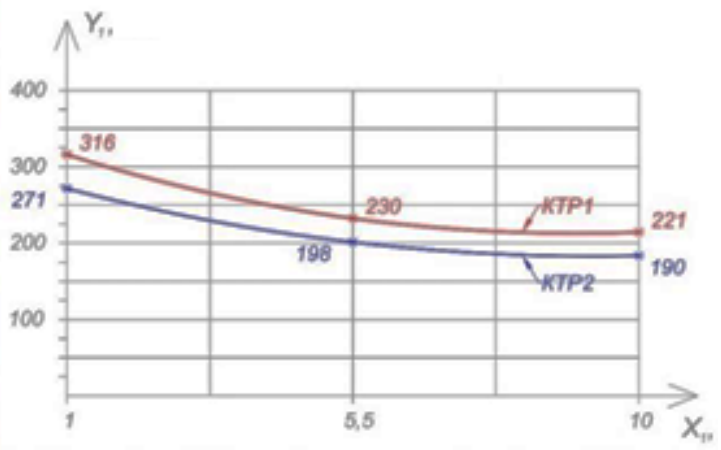

$X_{2}=5$ persons .

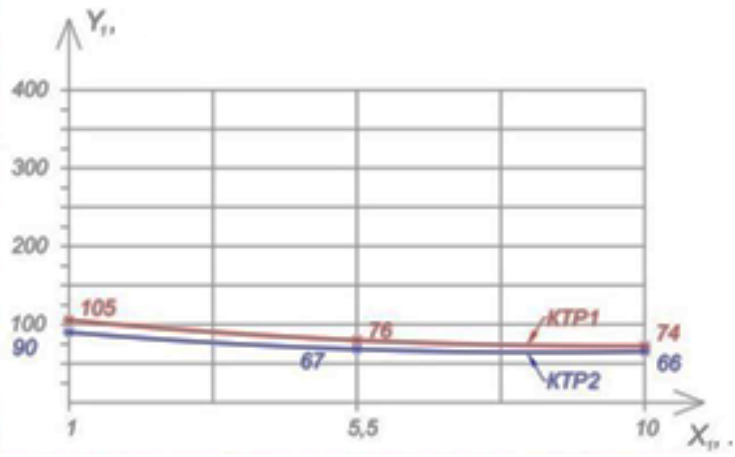

$X_{2}=10$ persons .

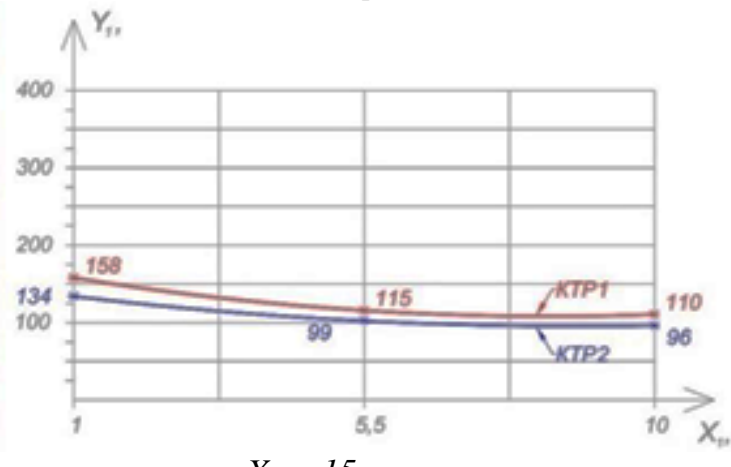

$X_{2}=15$ persons.

Fig. 6. Duration mounting temporary supporting structures $\left(Y_{1}\right)$ when changing the factor $X_{1}$ and $X_{2}$ fixation at levels of 5, 10,15 people for different constructive-technological decisions of temporary structures 
Let us analyze Figure 7. Change in $\mathrm{Y}_{2}$ (total project costs with charges), depending on the level of factor $X_{1} 2255,9-3971,9$ thousand. Rub., Which corresponds to $2,4-4,3 \%$ of the total costs. Such a small change in the index (in relative terms) is obviously due to the small proportion of fixed costs as a part of the total cost of the project emergency measures.

Consider Figure 8. Note that the behavior of the index $\mathrm{Y}_{3}$ (the intensity of the funding for the project) slightly varies when changing the structural and technological solutions metalwork columns.

The nature of changes in the rate under the influence of the factor $X_{1}$ is unchanged in all areas of the factor space. In general, the influence parameter on the factor $\mathrm{X} 1$ is small and the change is equal to $16-27 \%$ response at various levels of Factor $\mathrm{X}_{2}$.

Figures 9-11 allow us to compare the behavior of the parameters depending on the level of factor $\mathrm{X}_{2}$ (number of workers employed in the installation of steel structures). The level of factor $X_{1}$ (degree of integration of mounted elements of columns) is fixed at one of three levels: $-1,0,1$ (1, 5.5 and $10 \mathrm{~m}$, respectively.).

The figure below plots changes in the indices for different CTE combined in a single diagram.

Consider Figure 9. On it shows the change indicator «duration temporary supporting structures mounted» in various subspaces factor (at different CTE). Note that the variation index under the influence of the factor depends on the $\mathrm{X}_{1} \mathrm{X}_{2}$ factor level. Thus, the difference between the minimum and maximum index value in the area $X_{1}=1 \mathrm{t}$. Of 210.6 days to 181.5 days and KTR1 for KTR2. At the same time in the area $X_{1}=10 \mathrm{~m}$. This difference is 147.3 days and 123.8 days, respectively.

In general, the influence parameter on the factor $\mathrm{X}_{2}$, and significantly change its level can change values in response 2.88-3.02 times for different subspaces factor. 


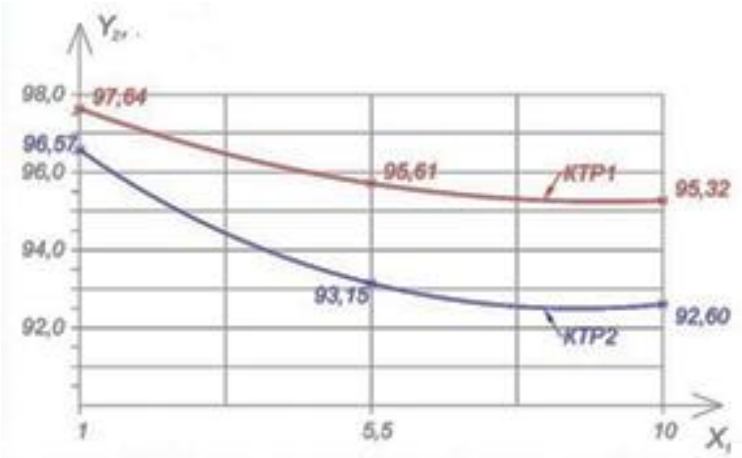

$X_{2}=5$ persons .

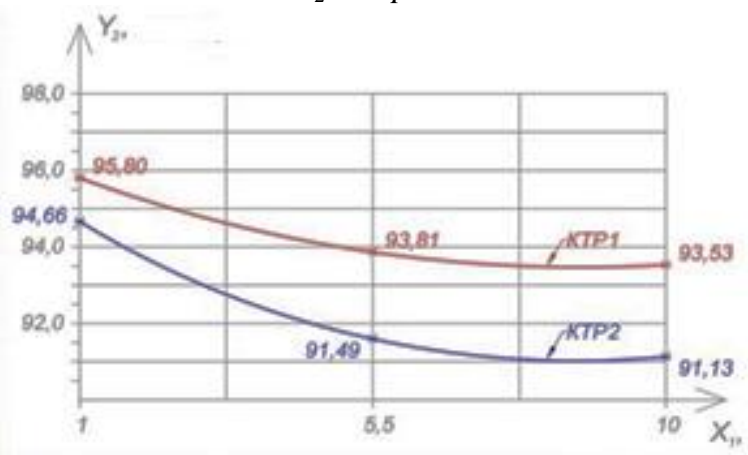

$X_{2}=10$ persons.

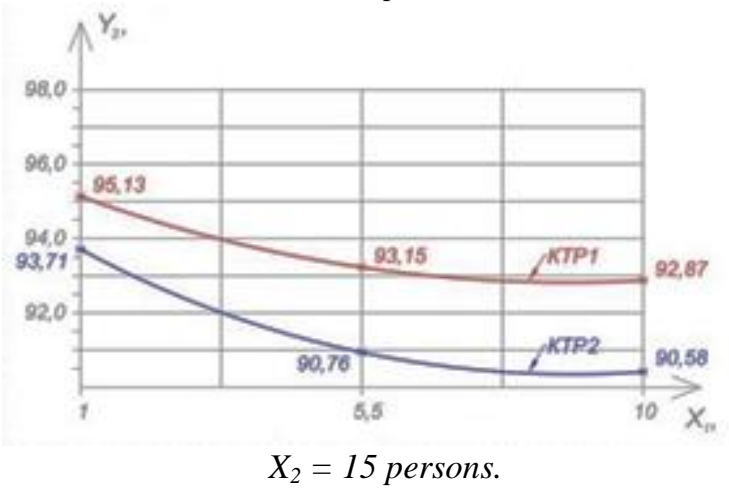

Fig. 7. The total cost for the project with charges $\left(Y_{2}\right)$ when changing the factor $X_{1}$ and $X_{2}$ fixation at levels of $5,10,15$ people for different constructive-technological decisions of temporary structures 


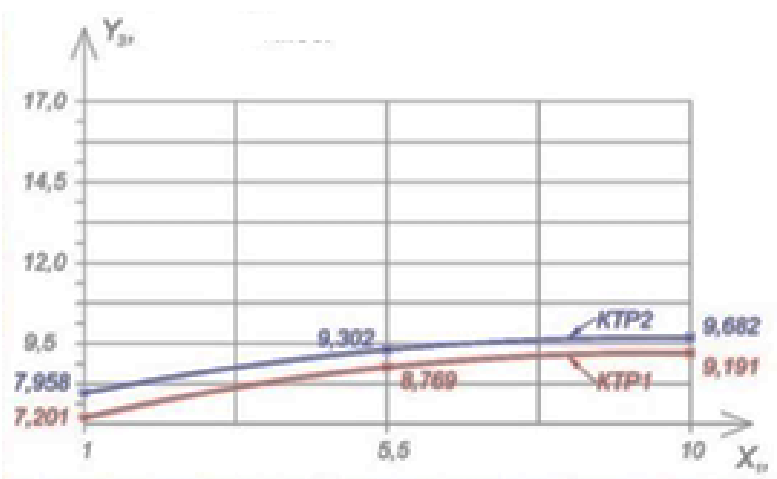

$X_{2}=5$ persons

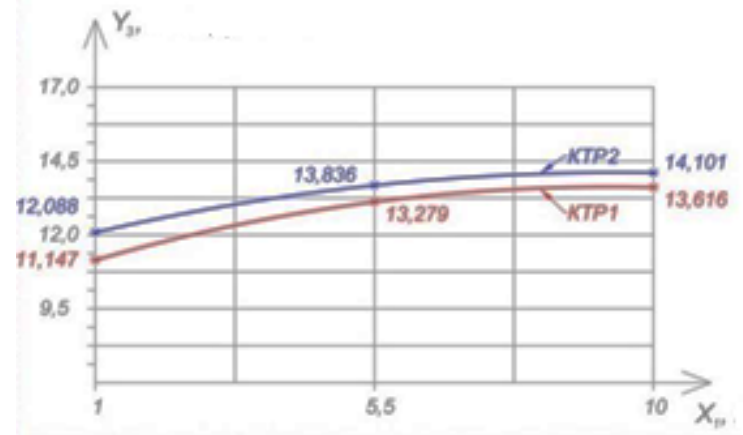

$X_{2}=10$ people

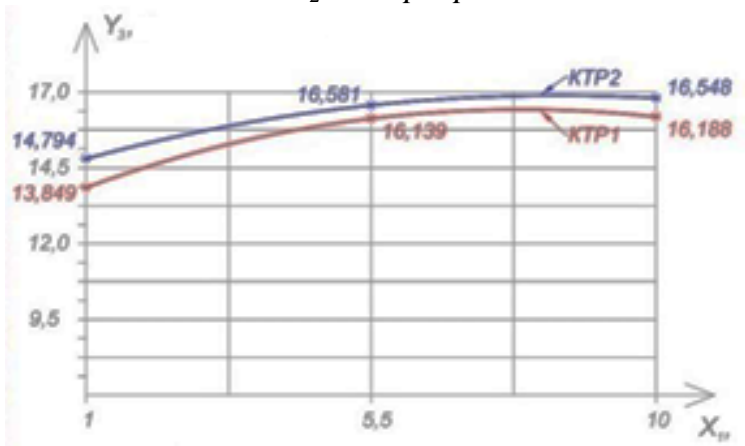

$X_{2}=15$ people

Fig. 8. The intensity of the funding for the project $\left(\mathrm{Y}_{3}\right)$ when changing the factor $X_{1}$ and $X_{2}$ fixation at levels of 5, 10, 15 people for different constructive-technological decisions of temporary structures 

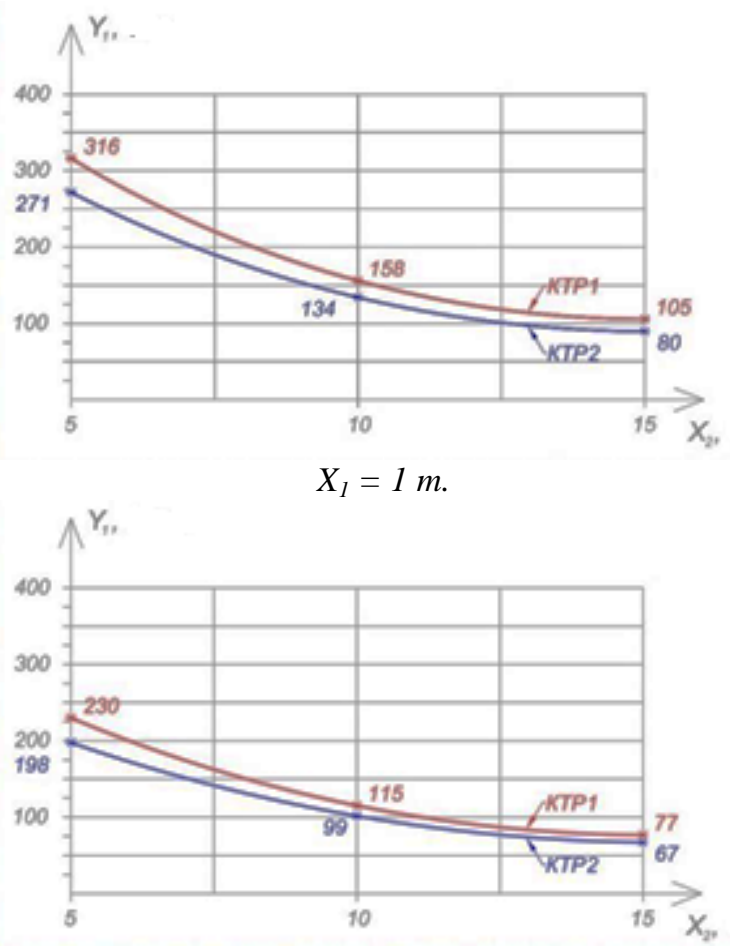

$X_{1}=5.5 t$.

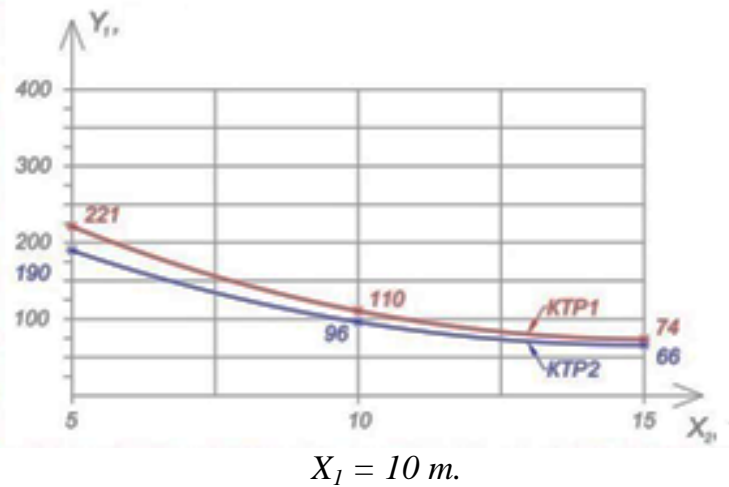

Fig. 9. Duration temporary supporting structures installation $\left(\mathbf{Y}_{1}\right)$ when changing the factor $X_{2}$ and $X_{1}$ fixation at levels $1,5.5,10 \mathrm{t}$. for different constructive and technological solutions temporaries 
In the analysis of Fig. 10 shows that increasing the level $\mathrm{X}_{2}$ slightly reduces the response value $-2 \%-$ as when using KTR1, KTR2 well. Compared with the effect of this change $X_{1}$ factor decreasing by $1-2 \%$, therefore, we can say that the factor X1 is somewhat greater influence on the index than $\mathrm{X}_{2}$ factor. The nature of changes in the rate is almost the same for all values of $X_{1}$.

Analysis figure 11 shows that the value of the index $\mathrm{Y}_{3}$ slightly different options for the building, designated as a constructive-technological decisions of temporary structures columns №1 and №2.

Also immaterial nature of the effect varies from $X_{2}$ to measure depending on the level $X_{1}$. The change indicator based on the level $X_{1}$ is 1,7-1,92 times for different subspaces factor.
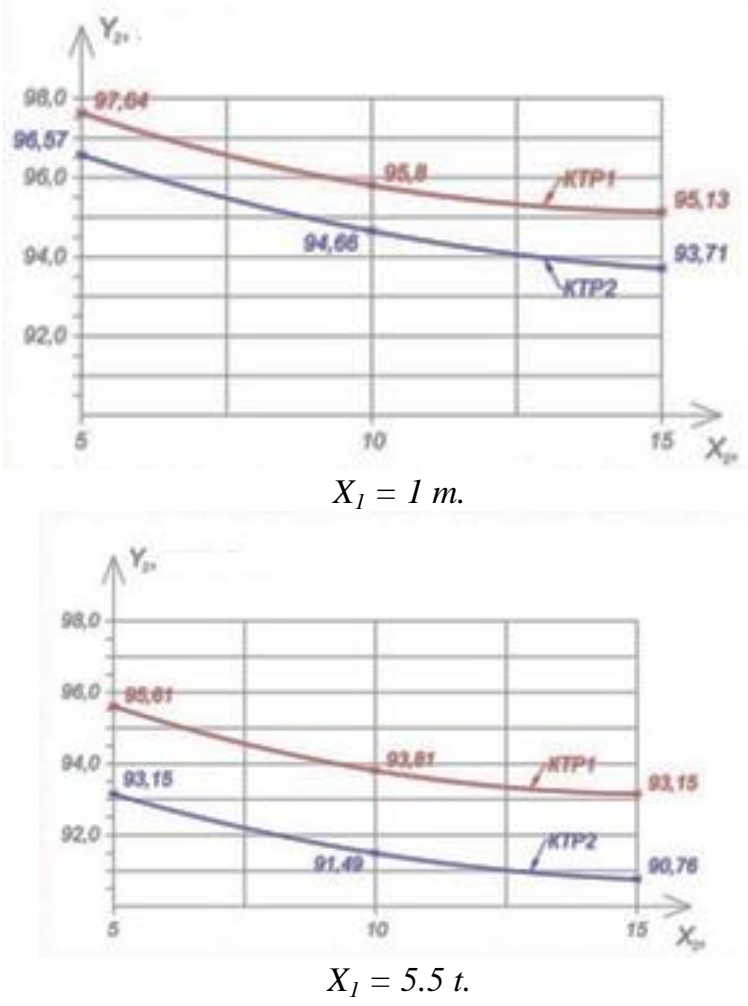


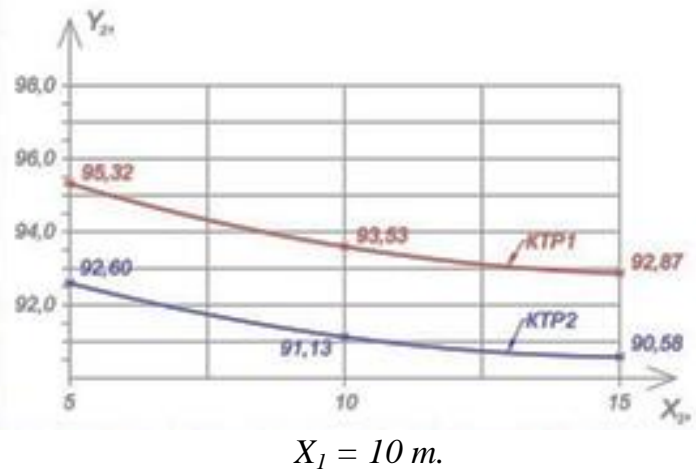

Fig. 10. Total costs for the project with charges $\left(Y_{2}\right)$ when changing the fixing factor $X_{2}$ and $X_{1}$ at levels 1, 5.5, 10 t. For different constructive and technological solutions temporaries
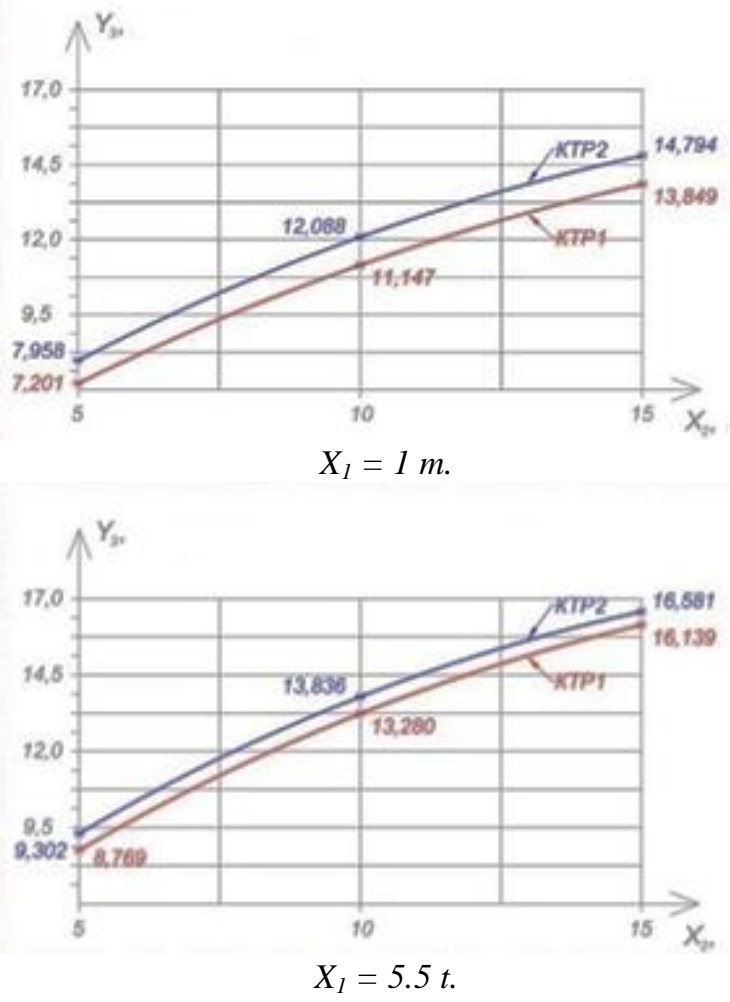


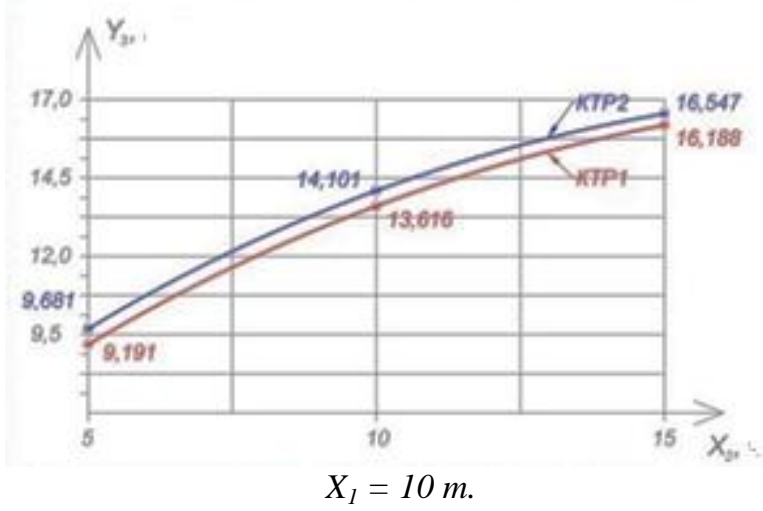

Fig. 11. Intensity project financing $\left(Y_{3}\right)$ when changing the fixing factor $X_{2}$ and $X_{1}$ at levels 1, 5.5, 10 t. for different constructive and technological solutions temporaries

\section{CONCLUSIONS}

1. In this paper we solved the problem of optimizing the design and technological solutions of emergency measures by the example of Shukhov radio tower. There were found regularities of change of the duration of the installation of temporary supporting structures, the total costs of the action with charges and monthly financing intensity of the project through the planning of numerical experiments and experimental-statistical modeling of manufacturing processes with the use of modern software products.

Used experimental design allows to get adequate results and to compare two versions of design and technological solutions of emergency measures at the levels of technological change (the degree of integration of elements mounted columns) and organizational (the number of workers employed in the installation of metal) factors.

Simulation of emergency measures showed a wide margin of changes in the studied parameters:

Duration of installation temporary supporting structures - from 316 to 73 days (4,33 times) with embodiment variant № 1; from 269 to 63 (at 4.27 times) with embodiment variant № 2 .

The total costs of the action with charges - 98474.2192906 .9 thousand rubles (6\%) under option variant № 1; from 96673 to 90539.65 (6.77\%) with embodiment variant № 2.

The monthly financing intensity of the project - from 7160.3816285 .84 thousand rubles/month (2.27 times) in the embodiment variant № 1; 7903.7216 642.98 thousand rubles/month (2.1 times) under option variant № 2. 
Analysis of factors influence the degree to figures revealed the following values of their ranking:

At time duration mounting bearing structures - the number of workers engaged in installation hardware $\left(\mathrm{X}_{2}\right) 100 \%$ with embodiment variant № 1 embodiment with $100 \%$ variant № 2; the degree of integration of elements mounted columns $\left(\mathrm{X}_{1}\right)$ at $32.7 \%$ variant № $1,34.8 \%$ with embodiment variant № 2 .

On the full cost of the project with charges $-X_{1}$ is $92.5 \%$ under option variant № $1100 \%$ under option variant № $2 ; 100 \% \mathrm{X}_{2}$ embodiment when variant № $168 \%$ with embodiment variant № 2.

The intensity of the funding for the project $-\mathrm{X}_{2}$ is $100 \%$ under option variant № 1 , is $100 \%$ under option variant № 2 ; is $32.9 \%$ when $\mathrm{X}_{1}$ variant № 1 variant, is $26.8 \%$ with embodiment variant № 2 .

\section{SUMMARY}

The paper analyzes the structural and technological design solutions for emergency repair works on engineering structures on the example of Shukhov Tower in Moscow. There were selected indicators that fully reflect the project of reconstruction and the most influencing factors. An algorithm was developed for optimizing organizational solutions by experimental statistical modeling and the use of modern software in the field of project management. There was considered the operation of the installation of steel structures for various design and technological solutions and proposed raising factors for cost and time-consuming work. There were developed organizational, technological, financial and economic model of the solutions under consideration according to the experimental plan. According to the values of the indicators there was fixed experimental design and was chosen the second degree polynomial model, which corresponds to the planned experiments. There was conducted simulation in specialized software and obtained experimental statistical laws change indicators (installation time, the full cost of the project, the funding intensity of the project) from factors (degree of pre-assembly mounted element metal constructions columns, the number of workers involved in the installation of the metal constructions) for two constructive and technological solutions (temporary welded hollow carrier columns with subsequent filling with concrete to the level of 24.65 $\mathrm{m}$.; flange provisional hollow bearing columns filled with concrete to the level of $1.50 \mathrm{~m}$.). There were presented results of experimental statistical modeling and optimization of the project under the given technological constraints on the possible conditions of work and project performance indicators. A graphical way was used to identify the most efficient models of construction in cramped conditions for their implementation. There were recommended optimal conditions for carrying out the construction work. 


\section{REFERENCES}

1. Вознесенский В.А. Статистические методы планирования эксперимента в технико-экономических исследованиях / В.А. Вознесенский // М.: Финансы и статистика, 1981. - 263с. 7.

2. Адлер Ю.П. Планирование эксперимента при поиске оптимальных условий / Ю.П. Адлер, Е.В. Маркова, Ю.В. Грановский // М. : Наука. - 1-е изд., 1971. - 283 с. - 2-е изд., 1976. - 279 с.

3. Налимов В.В. Теория эксперимента. / В.В. Налимов // М. : Наука, 1971. $-208 \mathrm{c}$.

4. Краковский Г.И. Планирование экспериментов / Г.И. Краковский, Г. Ф. Филаретов. // Минск: БТУ, 1982. - 757 с.

5. Вознесенский В.А. Численные методы решения строительнотехнологических задач на ЭВМ / В.А. Вознесенский, Т.В. Ляшенко, Б.Л. Огарков // К. : Вища школа, 1989.-328. с.

\section{Information about the author:}

Menejljuk O. I.,

Doctor of Technical Sciences, Full Professor, Odessa State Academy of Civil Engineering and Architecture 4, Didrihsona str., Odesa, 65029, Ukraine 